\title{
ETHNOGRAPHY
}

DOI: https://doi.org/10.32653/CH152224-248

Barry H. Rodrigue,

Ph.D, Professor of Anthropology

Symbiosis International University, Pune, India

rodrigue@archinets.org

\section{HUMANITY IN THE META-GALAXY: ANTHROPOLOGY'S SHIFTING PERSPECTIVES}

\begin{abstract}
We humans engage in a constant process of enlarging our understanding of the world around us. As our ancestors spread throughout Africa and beyond, they developed innovative strategies for survival - from tools and clothing to languages and customs. When dispersed human groups came into contact with each other, they shared ideas and genes. Self-awareness is a result of such interactions. This merging led to intercultural thinking of humanity as a global community, which in turn led to the birth of what we call anthropology. It was a method of self-actualization - by better comprehending our place in the world, we adapted ourselves and our surroundings. We are again at the threshold of a new self-awareness, a product of the consolidation of scholarship and global contacts to form what has been called cosmic evolution, big history, and universal studies. This expanded worldview is a product of taking a sense of a unified humanity to the next level - to the recognition that we are but one of many symbiotic life forms on Earth and but one entity within a much larger cosmos .
\end{abstract}

Keywords: Anthropology; Civilization; Universal Humanity; Multiverse; Big History. 


\section{ЭТНОГРАФИЯ}

DOI: https://doi.org/10.32653/CH152224-248

Родриге Барри,

д.ф.н., профессор антропологии, Международный Университет Симбиоза, Пуне, Индия rodrigue@archinets.org

\section{ЧЕЛОВЕЧЕСТВО В МУЛЬТИВСЕЛЕННОЙ: МЕНЯЮЩИЕСЯ ПЕРСПЕКТИВЫ АНТРОПОЛОГИИ}

Аннотация. Мы, люди, участвуем в постоянном процессе познания окружающего нас мира. Поскольку наши предки распространились по всей Африке и за ее пределами, они разработали инновационные стратегии выживания - от инструментов и одежды до языков и обычаев. Когда рассредоточенные человеческие группы вступали в контакт друг с другом, они делились идеями и генами. Самосознание является результатом таких взаимодействий, которые привели к восприятию человечества как межкультурного, глобального сообщества, к рождению того, что мы называем антропологией. Это был метод самореализации посредством лучшего понимания своего места в мире. Мы адаптировали себя и наше окружение. Мы снова на пороге нового самопознания - результата консолидации науки и глобальных контактов, того, что называется космической эволюцией, большой историей, универсальными исследованиями. Это расширенное мировоззрение - продукт перехода чувства единого человечества на следующий уровень - к признанию того, что мы - всего лишь одна из многих симбиотических форм жизни на Земле и всего лишь одна сущность в гораздо большем макрокосме.

Ключевые слова: антропология; цивилизация; универсальное человечество; мультиверс; большая история.

\section{Anthropography}

When did human self-consciousness expand beyond the level of other animals to become a focus of society? Did it happen for our Australopithecine ancestors three million years ago? Were the half-million-year-old shell-etchings of Homo erectus in Java an expression of that curiosity, or the Neanderthal stone rings in Occitania? Certainly, the cave and rock art of early humans in Africa and Eurasia and Australia demonstrates studied engagement with the world. 


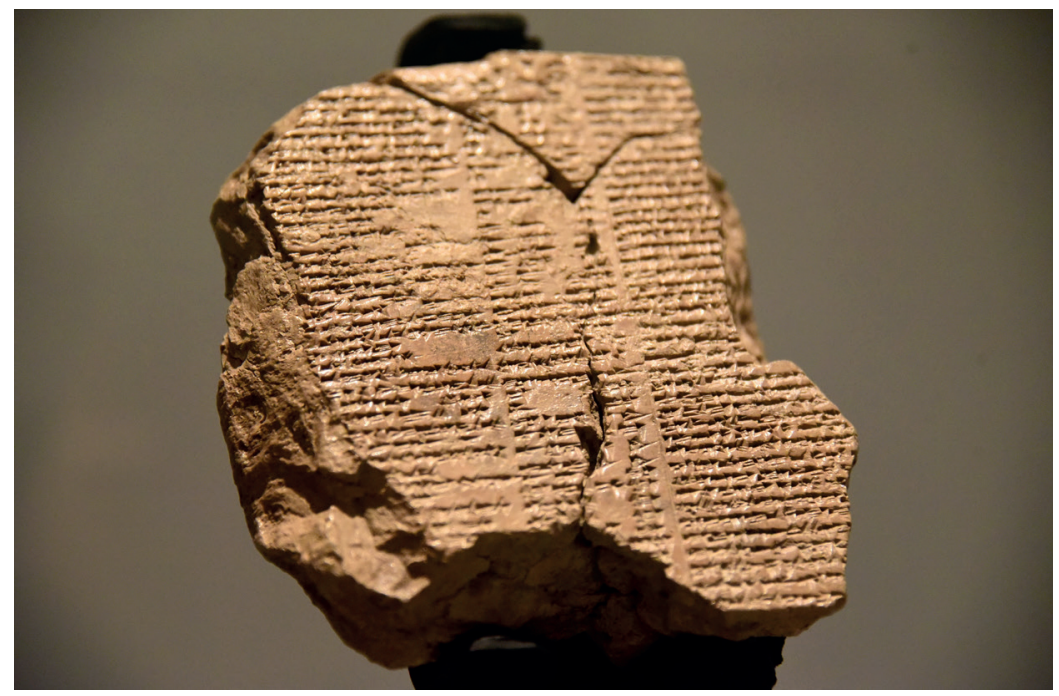

Image 1. Recently discovered cuneiform Tablet V of the Gilgamesh Epic, c 1800 BCE, which provides fresh insights about ethno-geographic encounters in the epic's Cedar Forest. Slemani Museum, Sulaymaniyah, Kurdistan, Iraq [2]. Photograph by Osama Amin, 2015, Wikimedia Commons

Рис. 1. Недавно обнаруженная клинописная Таблица V Эпоса о Гильгамеше, датируемая приблизительно 1800 г. до н.э., предоставляет новый взгляд на сражения в Кедровом Лесу. Музей Сулеймании, Сулеймания, Курдистан, Ирак [2]. Фотография Осамы Амина, 2015, Wikimedia Commons

At some point, mystical conjecture fused with practical knowledge to form a continuum of human understanding about the world. Inside the Epic of Gilgamesh, for example, a story of the search for eternal life mingled with encounters between Palaeolithic and Neolithic peoples. This fusion of ideas certainly did not provide a seamless fabric of awareness, but it was a beginning, an incipient form of anthropology and big history.

Something as simple as the repurposing of artefacts in Palaeolithic times indicates human connections with their past. This process increased during the Neolithic, as growing population densities and more extensive forms of farming, industry and habitation led to the recycling of artefacts to supplement new activities. Reuse of structural remains became so common in ancient Egypt that admonitions against such spoliation were proclaimed by dynastic officials in the second millennium BCE [3: 2785-2796; 4; 5: 89-110; 6: 223235]. We can thus see the roots of anthropography, the study of cultural literacy, as having its origin in the deep shadows of our ancestors' existence.

Writing systems led to better preservation of human ideas about their engagement with the world. We see how Shang dynasty oracle-bone inscriptions from 3200 years ago expressed concern about their votaries' place in society, the landscape, and the cosmos [7: 13-24; 8: 84-94]. Soon afterwards, a surge in human self-reflection appeared in works by Wenamun, Sappho, Laozi, and Mahavira. Some refer to this as an axial age, but it was as much a result of the wider use of writing ${ }^{1}$.

1 For big history considerations of the Axial Age, see [9: 183-196; 10: 118-123]. 

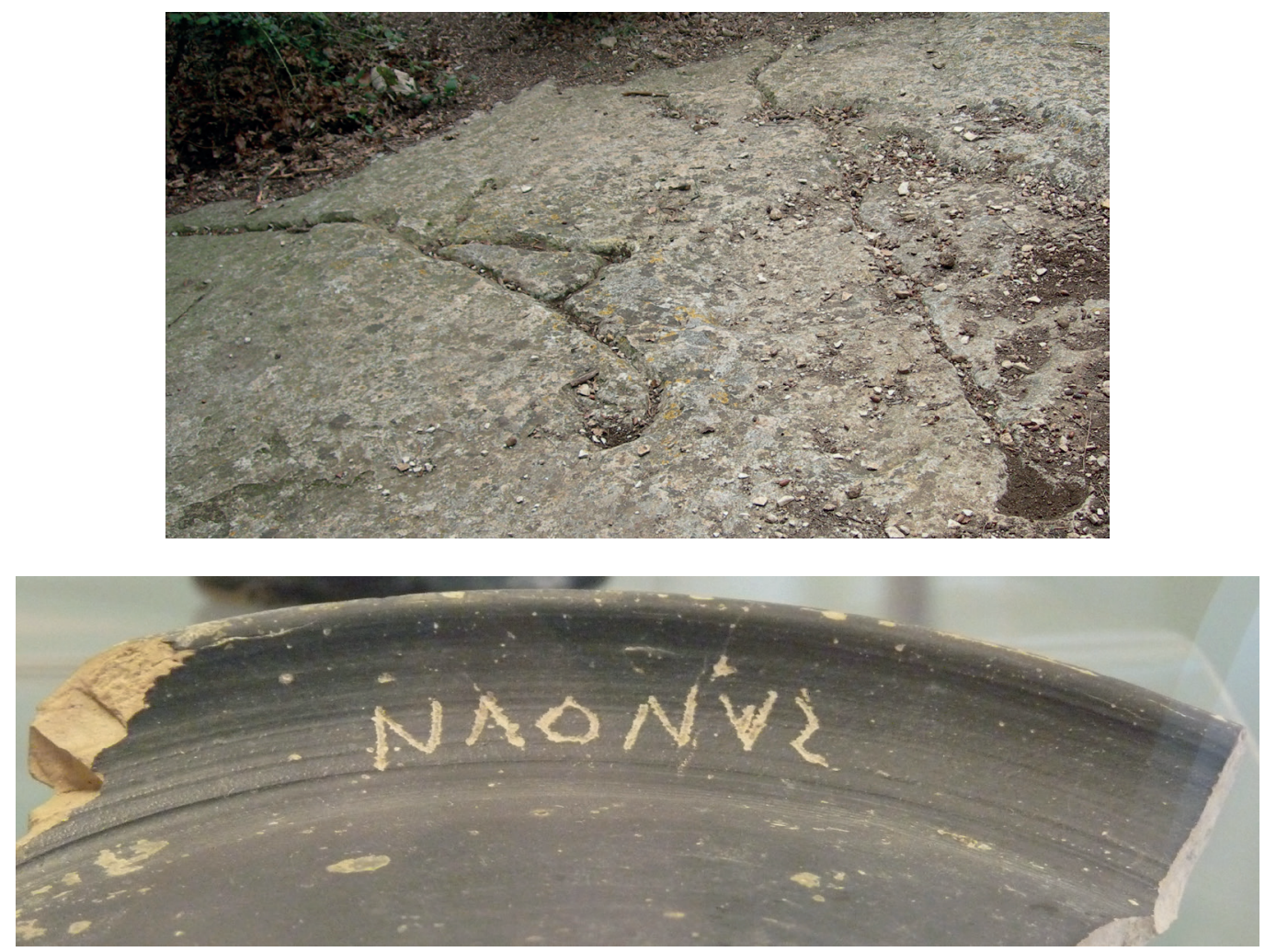

Image 2. Petroglyphs and a Picenean inscription found in the vicinity of Mt. Conero in Italy. Photographs by Alessandro Montanari (above) and Roland Saekow (below) ${ }^{2}$

Рис. 2. Петроглифы и Пиценские надписи, найденные в окрестностях Монте Конеро в Италии. Фотографии Алессандро Монтанари (верхнее фото) и Роланда Саекова (нижнее фото)

The rise of Neolithic class structure and leisure time for elites led to a more focused curiosity about the past. The Tisbury Hoard from Wiltshire (England) included items whose dates span a millennium, and so they are considered an artefact collection of the ninth century все. Neo-Babylonian King Nabonidus, in the sixth century все, established a museum in Ur (Iraq) curated by his daughter, Ennigaldi [14; 15: 15-16]. In this fashion, collecting artefacts became a strategy to empower leadership, along with its artisanal panoply of graverobbers, treasure hunters, and traders.

This self-reflection about heritage resulted from wider social interactions and deeper political structures, which manifested themselves in increased cross-cultural expressions, as when King Darius I of Persia commissioned a proclamation etched in three cuneiform languages onto a cliff face in the Zagros Mountains, along the road to Mesopotamia, 2500 years ago. The Bisotun inscription is an imperial account of conquest, but, since the Persian empire was a multicultural polity, it also illustrated intentional interaction between its different societies [16].

2 Many representations of early peoples' understanding of themselves and their surrounding world are still undecipherable, such as the petroglyphs and Picenean inscriptions found around Mt. Conero in Italy [11: $93-98 ; 12 ; 13]$. 


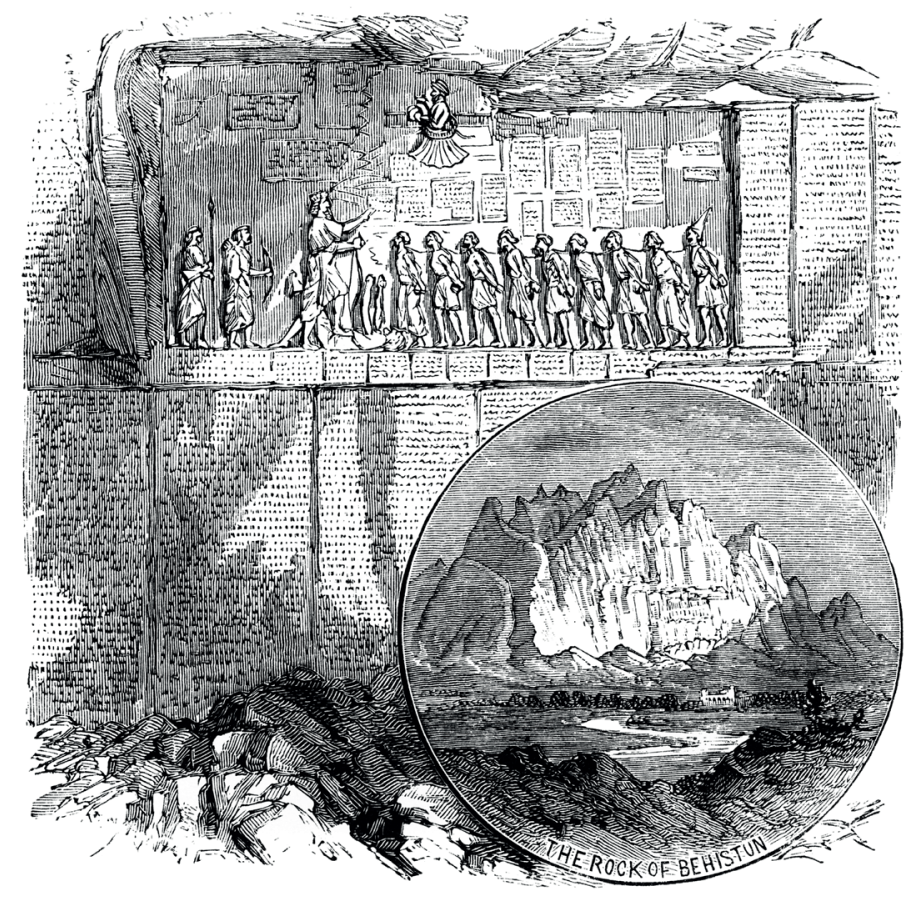

Image 3. Bisotun inscription. John Quackenbos, I

llustrated History of Ancient Literature, Oriental and Classical, New York: Harper \& Brothers, 1882, p. 65

Рис. 3. Бехистунская надпись. Джон Квакенбос, Illustrated History of Ancient Literature, Oriental and Classical, New York: Harper \& Brothers, 1882, c. 65

Anthropological studies are often dated to Herodotus, a scholar who had set out to document the struggle of the Persian Empire to annex the Greek states in the fifth century все. Since the invading Persian forces were multicultural, his resulting Histories expanded into a wide-ranging regional study of cultures, customs, and languages. This contemplation of human societies was continued by later Mediterranean scholars, from Tacitus and Ptolemy to Pausanias. Although deep literacy was still not common, public reading by lettered retainers allowed narratives to reach a wider audience and encouraged interest in other peoples and places [17: 12-28].

Some, like philosopher-poet Lucretius in his verses On the Nature of Things in the first century всE, expressed a materialist view of the universe and a unitary sense of humanity, presaging anthropology and big history by hundreds of years. Literacy grew with the technology and infrastructure supporting it. Travellers' accounts became popular, as with Faxian's journey from China to India to collect Buddhist documents in the fifth century CE or Aḥmad ibn Faḍlān's envoy from the Caliph of Baghdad to the Volga Bulgars in the tenth century ${ }^{3}$.

3 Although known in the ancient Mediterranean world, Lucretius' writing was lost and only rediscovered in an archive in 1417, providing an impetus to Renaissance thought. His ages of humankind was re-demarcated by antiquarian Christian Thomsen in 1834 as Stone Age, Bronze Age, and Iron Age [18]. The tradition of travellers' narratives intensified during the Renaissance, as with those of Benjamin of Tudela in the twelfth century, Giovanni da Pian del Carpine in the thirteenth century, and Muhammad Ibn Bațuțah in the fourteenth century. 
Their observations of foreign customs entered a variety of activities, from political policy and geographic reports to religious discourse and popular story-telling. Along with literacy, schools began for elite males and those with noted skills. Centres for learning sprang up in places like Nalanda (India), which drew students from around Asia, while Inca aristocracy along the Andes attended the yachay wasi (house of knowledge) for instruction in reading quipu, mathematics and public affairs. In this way, questioning of the wider world was debated in academic settings but then percolated through society as students returned to their home communities.

Much cross-cultural material also existed in non-public works. Evidence of this came from the Cairo Geniza, a Jewish document repository of the last millennium that held rich detail of cultural interaction by merchants from the Mediterranean through the Arabian Peninsula to India and beyond. Indeed, Marco Polo's thirteenthcentury Travels, with its rich descriptions of Asia, was the narrative of a business venture that only came to be recorded by happenstance $[19 ; 20 ; 21]$.

In Europe, Renaissance discovery of Classical knowledge in scriptoriums and the libraries of Al-Andalus not only revived interest in ancient scholars like Herodotus and Lucretius but also required researchers to negotiate exotic cultural traditions so as to access the materials. A manifestation of this upsurge in knowledge was a demand for relics, so much so that Papal authorities interdicted the black-market export of Roman artefacts in 1461. The Vatican also began public exhibition of heirlooms on Capitoline Hill a decade later to foster cultural pride [22: 1-20; 23: 44-45].

Nor was this new intercultural awareness confined to Eurasia, as we see contact with the Americas going back prior to the Columbian exchange, as with Polynesian voyages to South America and transient European settlement in North America over a 1000 years ago. What effect did these meetings have on the societies involved? It is unclear, but a market developed for imaginative stories, as in the aja'ib and mirabilia genres of 'wonder' tales [24: 2205-2210; 25; 26].

The slow pace of these contacts and regional political consolidations set the stage for a more intense period of globalization. Just as millennia of encounters slowly encouraged intergroup reflection, a fierce period of worldwide engagement began in the fifteenth century and forged an even more integrated understanding of humanity's place in the world. The process was not new, but it was more frenzied and is still going on today. It was the profound impact of this new globalization that led to the modern formulation of both anthropology and big history.

\section{Globalization}

European colonial expansion in the fifteenth century led to profound changes in understandings about humanity, but there was no metaphysical quality of European society that unleashed their hegemony on the world. The process can be described in a 'Global Algorithm':

Asian invention + Afro-American resource + European gestalt $=$ Global civilization 
The formula's categories are shorthand for physical and intellectual exchange. Of course, this global dynamism was far more complex than a mere algorithm can convey, but it seeks to illustrate that - far from being just a European-driven phenomenon - the new global engagement had grown from the vast silk-route network into a planetary sphere of interaction that is more properly designated as 'Global civilization'4.

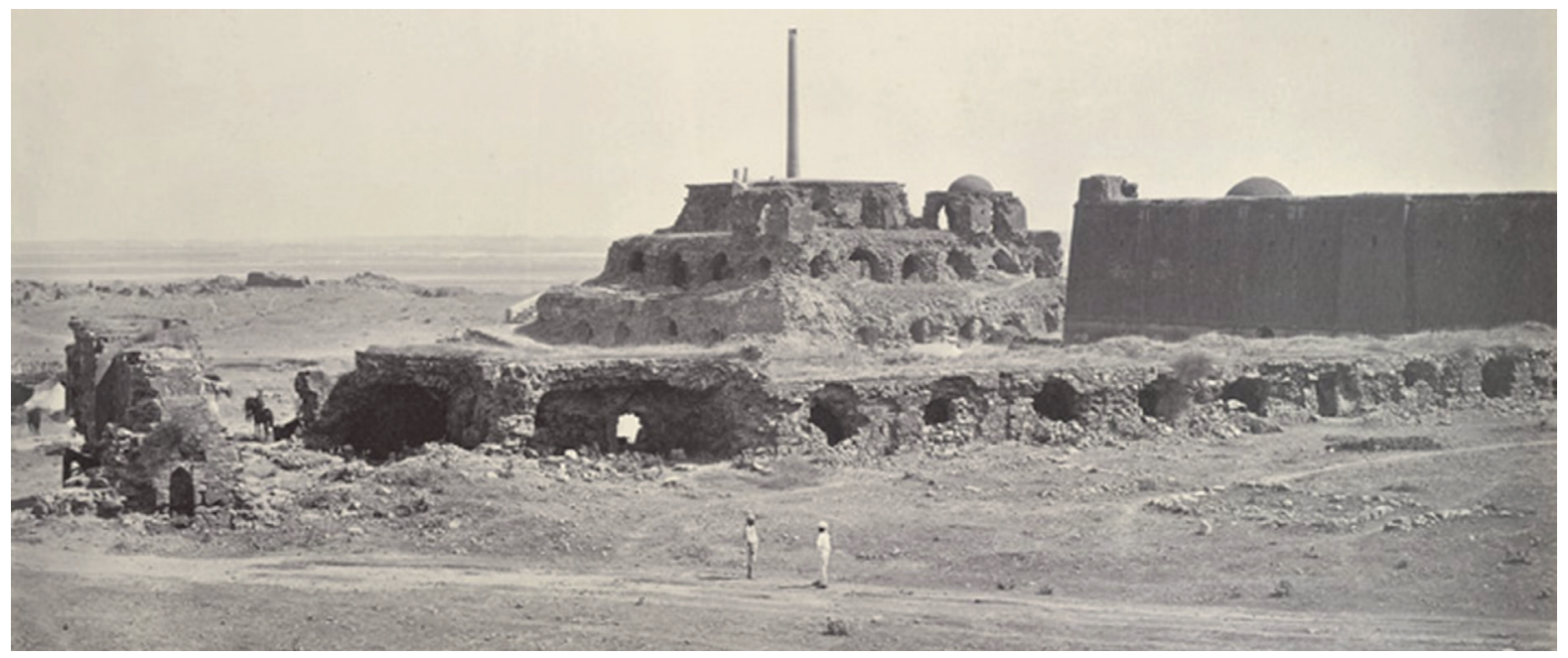

Image 4. Sultan Firoz Shah Tughlaq of the Delhi Sultanate had this Ashokan pillar (third century BCE) removed from Topra Kalan (Haryana) to Firozabad as part of his antiquarian collections in $1356 \mathrm{CE}$. The use of monumental stoneworks fused with the collection of artefacts to create a form of antiquarianism that sought to legitimize rulers ${ }^{5}$.

The column now is within the bounds of Delhi, India. Photograph by Samuel Bourne, 1860, British Library Online Gallery

Рис. 4. Султан Фироз Шах Туглак из Делийского султаната вывез эту колонну Ашоки (III век до н.э.) из Топры Калана (Харьяна) в Фирозабад для своей коллекции антиквариата в 1356 г. Использование монументальной каменной кладки слилось с коллекцией артефактов для создания некой формы антикварности, которая стремилась узаконить правителей. Колонна сейчас находится в Дели, Индия.

Фотография Сэмюеля Борна, 1860, онлайн-галерея Британской библиотеки

This global process can be seen at work when Mughal emperor Akbar I (15421605) institutionalized the concept of Sulh-i-Kul (universal peace), which sought to harmonize cultural and spiritual traditions from around Eurasia and the world. Originally developed by Sufi scholar Ibn Arabi of Iberia in the twelfth-century, his philosophical ideal drew courtiers to South Asia and led to wide communication, as in Akbar's celebrated correspondence with Phillip II of Spain and others [28: 84-103].

In Europe, aggressive colonialism and Enlightenment efforts to understand their expanding worldviewled to new thoughts of how things fit together. Giambattista Vico's The New Science (1725) built a framework of universal history, while Carl Linnaeus'

4 This reassessment of global civilization parallels that of later interpretations in anthropology (see the text linked to endnotes 21 and 22 on professionalization in respect to UNESCO and the British Museum).

5 Firuz Shah Tughlaq's collection of antiquities was in a tradition that had existed earlier in the Mamluk dynasty and would continue in the Mughal empire. He was also a celebrated collector of other antiquities, having ancient documents translated into Arabic [27: 994-1010]. I would like to thank historian Afshan Majid for sharing this example of South Asian antiquarianism. 
Systema Naturae (1735) constructed a matrix of biological connectivity. Denis Diderot and Jean le Rond d'Alembert's Encyclopédie (1751+) sought to amalgamate knowledge into useful forms for people's use. Johann Friedrich Blumenbach is considered one of the first modern anthropologists. His dissertation at the University of Göttingen, On the Natural Variety of Humankind (1775), was an anatomical classification of human races, but it premised a single human species with all groups having equal potential and variations being the result of environmental factors ${ }^{6}$.

Human studies were not well demarcated at this time, as artefacts, languages and folklore were lumped together as 'antiquities' and came to be linked to notions of historical romanticism and nationalism [30] As the wealth generated by global trade trickled through society, new infrastructures for the study of humanity resulted. The Society of Antiquaries of London emerged from a Westminster tavern in 1717, when a group met to discuss how to preserve historic buildings. It was a domain of amateurs, where the banal coexisted with the erudite. In 1794, William Shakespeare's head was looted from his tomb to satisfy an influential English antiquarian. Two decades later, folklorist and author Walter Scott wrote of these contrasting values in his best-selling novel, The Antiquary [31; 32; 33].

Scholars struggled to make sense of the facts, minutiae and notions that were jumbled together by antiquarians. Neo-Confucian scholar Miura Baien (1723-1789) merged Japanese concepts with Chinese and European ideas to develop a new vision of the world, one that has been compared favourably with the later studies of Alexander von Humboldt7. In Tibet, such intercultural views coalesced to produce new visions of interaction, as in The Detailed Description of the World (1830), a synthesis of Tibetan worldviews with cosmopolitan ideas acquired in China. However, when Lobsang Palden Chopal, the Chief Minister in Shigatse, sought to expand on such new knowledge fifty years later, he was executed by a Tibetan government fearful of Russian, British, and Chinese encroachment ${ }^{8}$.

Many Europeans viewed human society as a stage of global and progressive advancement, but one in which western European society formed the leading edge, a logic that often became justification for overseas expansion9. In 1784, European colonials established the Asiatic Society of Bengal, which set up the Oriental Museum

6 The first edition of Blumenbach's book was a privately produced version of his dissertation that he published in 1776. It went through many editions and appeared in many languages. For example [29].

7 Miura's work was hampered by foreign and domestic policies of the Tokugawa shogunate and so became lesser known than those of other scholars [34: 389-421]. My appreciation goes to Nobuo Tsujimura for bringing Miura to my attention.

8 Btsan po no mon han (1789-1839) was a lama of the Drepung monastery in Lhasa. In about 1814, he travelled to Beijing, where he spent the rest of his life. His Detailed Description of the World was first published in Mongolia in 1830, but it had been a work in progress for more than a decade [35: 73-134; 36; 37: 300-311]. Lobsang Palden Chophel was the Sengchen Lama and Chief Minister in Shigatse, Tibet. A modernizer and internationalist who took an active interest in science, languages, and technology, his execution in 1887 was the result of his unwitting friendship with British operative Sarat Chandra Das, from whom he learned of advances in Western innovation [38: 108-110; 39: 263-279].

9 There had been a long tradition of documenting cultures to aid political and military goals. Programs dealing with intercultural affairs began in order to facilitate discovery and conquest of territories, then to acquire information for governing colonies and managing trade. China especially had a long tradition of such efforts [40: 623-662]. 
in Kolkata thirty years later, the oldest collection of its kind in India. Initially run by Europeans, local elites were finally allowed to join after 1829, including members of the celebrated Tagore family of artists and scholars [41: 214-215; 42: 38-41].

European colonialism exacerbated problems of overseas appropriation of cultural materials, such as the Parthenon marbles' acquisition by the Earl of Elgin in 1801 (during the Ottoman Empire's control of Greece) and their placement at the British Museum. The colonial traffic in antiquities led Egyptian ruler Mohamed Ali Pasha to ban artefact exports in 1835 and establish a storehouse for them. In 1858, his son created the Antiquities Service, which oversaw excavations in Egypt, and began the first museum in the Middle East five years later [43: 1880-1923; 44: 109-121; 45].

The mid-century impact of evolution and materialist thought on society was profound. Although evolutionary theories and timeframes had earlier existed, the mechanisms were not so well enunciated as those by Charles Darwin (1859), Herbert Spencer (1862), and Karl Marx (1867). Spencer's theories especially had an impact on anthropological thought, along with those of anthropologists Edward Burnett Tylor (1871) and Lewis Henry Morgan (1877) [46-50].

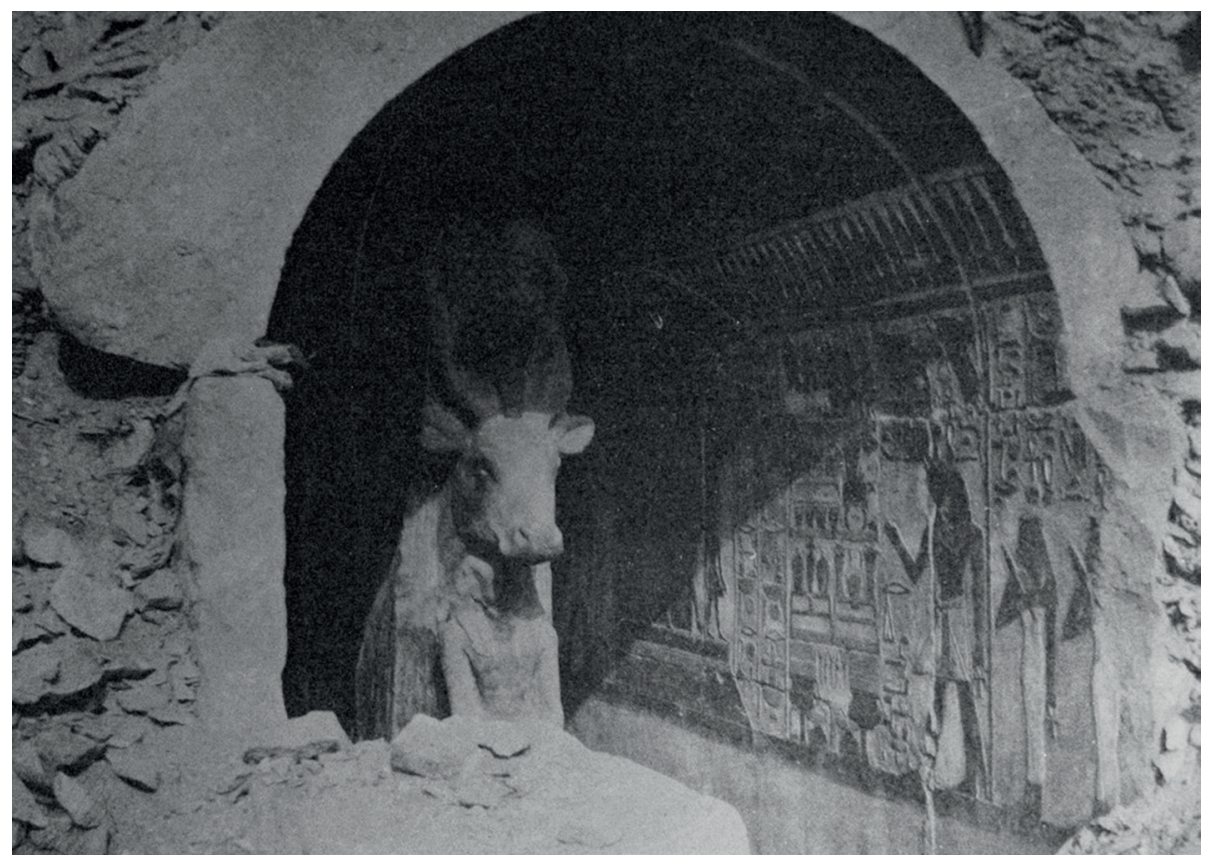

Image 5. Hathor shrine (fifteenth century BCE), Deir el-Bahari, Egypt. The remains are preserved in the Museum of Egyptian Antiquities in Cairo. Photograph by Henri Naville, 1907, Wikimedia Commons

Рис. 5. Святилище Хатхор (15 в. до н.э.), Дейр эль-Бахри, Египет. Останки хранятся в Египетском национальном музее в Каире. Фотография Эдуара Навилля, 1907, Wikimedia Commons

People certainly knew of the many varieties of cultural expression at this time, but the overarching concept of culture was just beginning to be identified and elaborated. In 1871, Tylor provided one of the first definitions of culture in its social context. 
Culture or Civilization, taken in its wide ethnographic sense, is that complex whole which includes knowledge, belief, art, morals, law, custom, and any other capabilities and habits acquired by man as a member of society [49:1:1].

Tylor saw anthropology to be in the lineage of universal history and interdisciplinary ${ }^{10}$. It thus came to be appreciated that anthropology was not just about 'things' that antiquarians collected but a matter of 'process' - in an interactive and evolutionary dynamic.

Human studies continued to be hampered by pseudo-scientific theory, which included crude notions of biological and social evolution that set-up hierarchies of superior and inferior species, races, and societies. These populist views served to justify institutions of class, caste and slavery, since those lower on a biased evolutionary tree could be considered non-human or un-civilized and deserving of diminished existence. Social contradictions came into a heated debate in Europe and its colonial outposts, as during the U.S. Civil War (1861-1865), a bloodbath that liberated African-American slaves but left them at the bottom of a racist social system. Scholarship began to more forcefully challenge such conceits, as research strengthened the precept that, despite differences, humans were a unified species. It was a long process that is still going on today ${ }^{11}$.

As the concept of a global humanity gained wider support, it led to the professionalization of human studies. Begun by amateurs, anthropology required little training or equipment. Folklore and linguistics was accessed by conversation and observation, while anyone with a shovel could begin archaeological excavation. Biological anthropology was seen as an extrapolation from everyday hybridizing of farm crops and livestock. In 1878, the secretary of the Smithsonian Institution noted that anthropology was the most popular branch of science ${ }^{12}$. Anthropologists did not need certification: One could enter the field as a self-trained amateur.

For example, as a young man, Edward Sylvester Morse (1838-1925) was known for his study of snails and his drafting abilities along the Gulf of Maine. He came to the attention of zoologist Louis Agassiz, who hired him to work at nearby Harvard University. Although lacking a degree, Morse became co-founder of the journal, The American Naturalist, as well as a lecturer at Harvard and a fellow of the National Academy of Sciences [58: 101-129; 59: 45-73].

10 Edward Tylor only circumstantially references Alexander von Humboldt's series Kosmos, but his intent is obvious from the context [49: 1-2, 17; 52; 53: 197-198].

11 An example of such transition is how physician Robert Knox saw a common base in not just human anatomy but between species, which led him to develop an early version of evolution that he called zoological history. He expanded his observations from anatomy to ethnology, which mirrored populist views of the time in privileging European society [54; 55]. Biologist Stephen Gould noted that science is embedded in subjective human culture and so has often failed to consciously address many social problems and its own biases in an objective way [56].

12 As an example of the ease of entry into human studies and its pervasive interest to the general public, it has been and is still common for farmers and other residents of North America to collect and display indigenous arrowheads and other artefacts that they have found while tending their fields or visiting historic sites. This is something I have frequently encountered in my own fieldwork [57: 45-51]. 
In the 1870 and 1880 s, Ned Morse went to Japan as an advisor on educational reform during the Meiji Restoration. His collection of brachiopods led him to discover the Ōmori shell mound and to identify Jommon culture (16,500 BP), while his study of Japanese ceramics and architecture cemented his reputation as an anthropologist. What began as an amateur passion developed into professional work. His international work and questions about the origins of Japanese society led to the founding the Anthropological Society of Japan in 1884 and the first academic journal of anthropology two years later. In 1892, a member of this group of scholars, Tsuboi Shogoro, became the first professor of anthropology at the University of Tokyo [60; 61: 91-92].

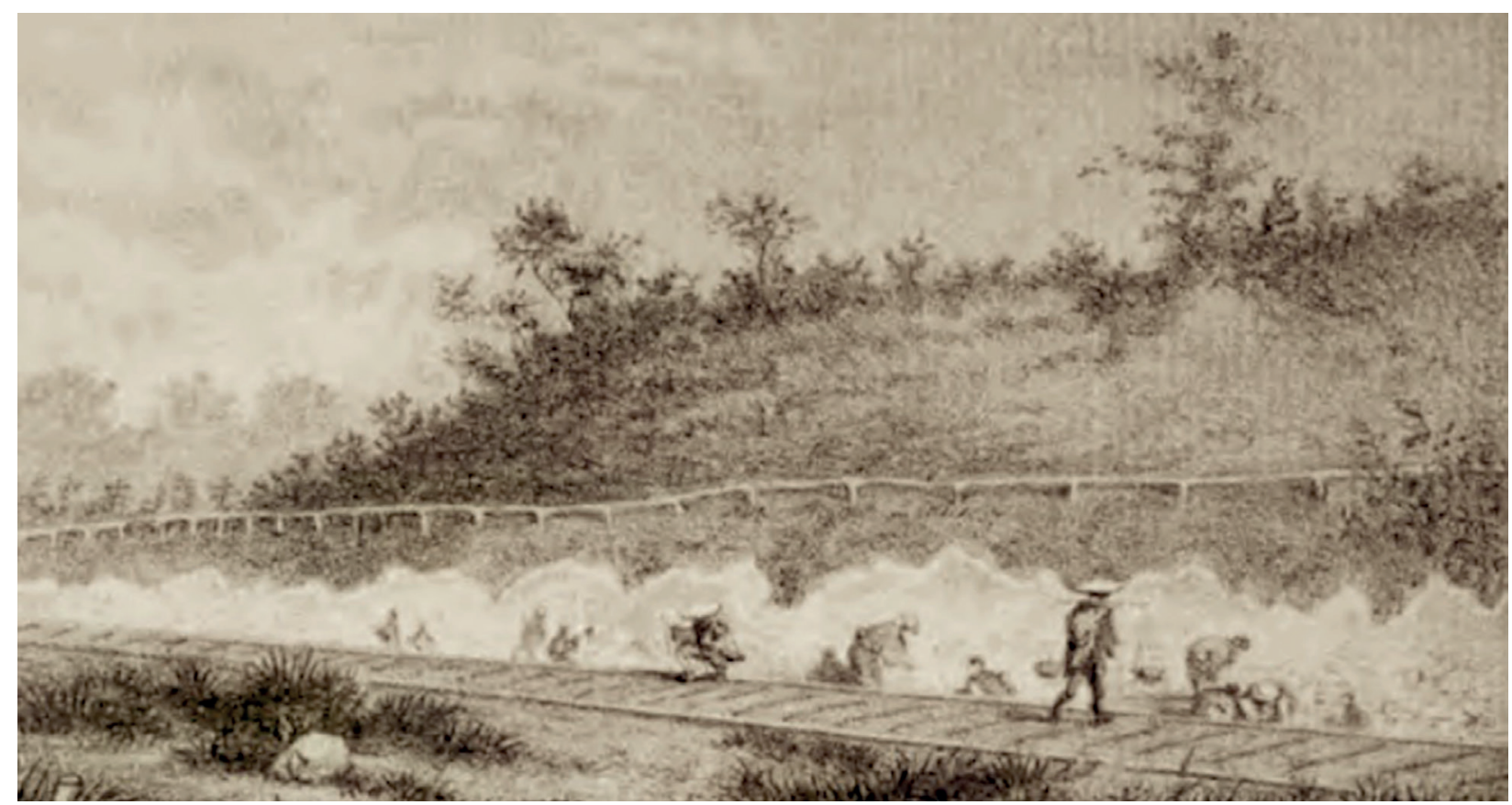

Image 6. Excavation of the Ōmori shell mound, Jōmon culture, Shinagawa (Tokyo), Japan, c 1877. Frontispiece, Edward Sylvester Morse, 'Shell Mounds of Omori', Memoirs of the Science Department, University of Tokio, Japan, vol. 1, part 1, Tokyo: University of Tokyo, 1879

Рис. 6. Раскопки Кухонной (Раковинной) кучи в Омори, Дземонская культура, Синагава, Япония, ок. 1877 г. Фронтиспис, Эдвард Сильвестр Морзе, 'Shell Mounds of Omori',

Memoirs of the Science Department, University of Tokyo, Japan, Vol. 1, part 1, Tokyo: University of Tokyo, 1879

In order to take advantage of amateur endeavours in anthropology, the British Association for the Advancement of Science published Notes and Queries on Anthropology: For the Use of Travellers and Residents in Uncivilized Lands in 1874. Adopting Tylor's vision of progressive social evolution, the volume proclaimed an inclusive view of humanity: 'History has confined itself chiefly to the achievements of special races; but the anthropologist regards all races as equally worthy of a place in the records of human development'. It also provided less noble suggestions: 'If after a battle, or other slaughter, the head of a native can be obtained with the soft parts in it, it might be preserved and transmitted carefully and perfectly closed up in a small keg filled up with spirit, or brine thoroughly saturated with salt' [62: IV, 142]. 
Different cultural traditions had fascinated people for millennia, and, as more studious works came into being, they continued to mingle with populist representations of humanity. The Great Exhibition in London and the Smithsonian Institution in Washington D.C. featured cultural exhibits from around the world, but so did P.T. Barnum's circus and Buffalo Bill's Wild West Show. Such populist and professional tensions led scholars to further specialize cultural studies, which led to the establishment of more schools of anthropology, journals, societies, a standard vocabulary, and regulations to protect antiquities [63;64: 149-158; 65: $370-411 ; 66]$.

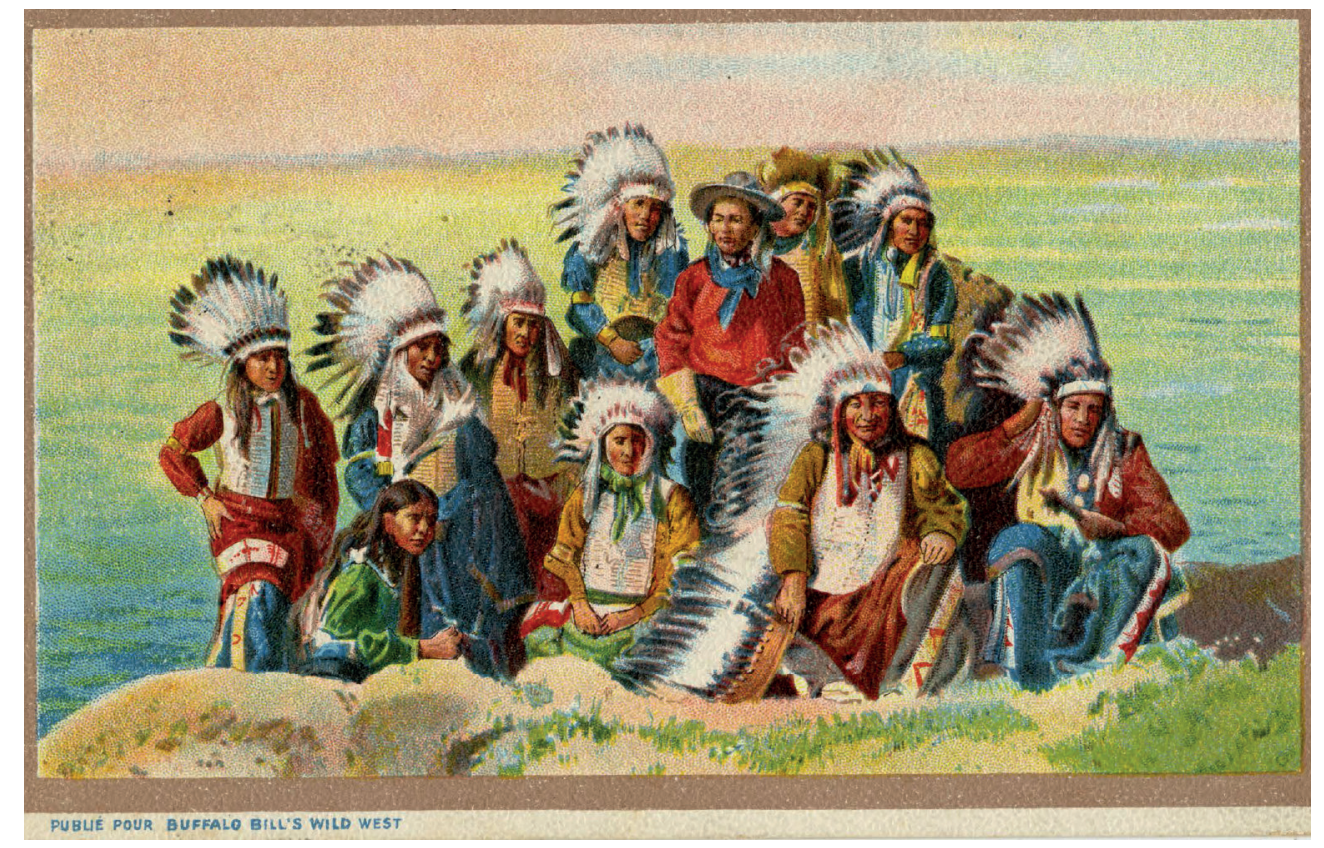

Image 7. French postcard, Buffalo Bill's Wild West Show, 1903. MS 327, James Wojtowicz Collection, McCracken Research Library, Buffalo Bill Center of the West, Cody, Wyoming, USA.

Рис. 7. Французская открытка Шоу Дикого Запада Буффало Билла, 1903. MS 327, Коллекция Джеймса Войтовича, Научная Библиотека МакКракен, Центр Буффало Билла на Западе, Коди, Вайоминг, США.

It is difficult to estimate the numbers of anthropologists engaged in work at this time. As university infrastructure divided into disciplines and departments in the late-nineteenth century, anthropology likewise segmented. Folklorists were found in literature departments, physical anthropologists in medicine, linguists in languages, archaeologists in geology, and ethnologists in sociology. In 1876, ethnographer Alfred Russel Wallace noted the 'chaotic state of the infant science of anthropology'13.

13 In 1898 , it was estimated that only 50 archaeologists were engaged in scientific research in the United States but that almost 5000 amateurs were also at work [67;68; 69; 70]. 


\section{Professionalization}

Anthropologists worked to document traditional culture at a time when indigenous societies were being rapidly transformed by industrial society and colonial contact. These inquiries led to more involvement by state agencies. When the United States became embroiled in wars with native peoples in its western territories, anthropologists like Alice Fletcher and James Mooney worked to establish the Bureau of Ethnology (1879) as a repository for tribal materials. In Britain, the Ordnance Survey had been charged with mapping as an adjunct to its military operations, but, by the midnineteenth century, its scope of work expanded to include archaeology, folklore and other landscape-related topics. Similar partnerships took place elsewhere, from South Asia to South America [71; 72; 73: 21-37].

In 1899, Franz Boas set up the first department of anthropology in the United States, at Columbia University, by bringing together the study of archaeology, ethnology, linguistics and physical anthropology into what became known as the four-field system. Other scholars were even more inclusive. Wilhelm Wundt began his academic career in Germany as a professor of anthropology and, although later celebrated as the founder of psychology, saw the "philosopher and historian, theologian and ethnologist in unified work' to understand humanity ${ }^{14}$. A key purpose of anthropology was to identify what it was to be human through interdisciplinary methods.

Although a study of culture was central to anthropology, identifying it as a concept only came as a result of comparative work, which Ruth Benedict illustrated in her Patterns of Culture (1934). Culture is almost unconscious - we don't think about how we walk, for example, we just do it as something learnt in our society. But by studying other traditions of walking, we come to appreciate our own tradition and are able to then formulate general theories about pedestrian behaviour. In this way, an examination of differences and commonalities between species, races, ethnicities and languages developed, which led to better theoretical understandings about how society functions $[75]^{15}$.

For example, ethnographers documented ceremonial exchange among remote peoples around the world. Franz Boas investigated the potlatch among the Kwakiutl in northern British Columbia (1921), while Bronislaw Malinowski studied the Kula Ring of the Trobriand Islanders in eastern New Guinea (1922). When Marcel Mauss conceptualized gift exchange as a form of social reciprocity (1925), these disparate phenomena were appreciated as a cultural artefact of humanity as a whole [77; 78;

14 Franz Boas' Anthropology Department institutionalized the four-field system to regain some of the synthesis lost when universities adopted departments and disciplines. Elsewhere, anthropology focused on social-cultural studies, with archaeology, linguistics and physical anthropology remaining in other departments. Variations resulted around the world. In my own Department of Anthropology in the School for Liberal Arts at Symbiosis International University, we use the four-field system, while neighbouring universities use the social-cultural approach. As anthropologist Elisabeth Tooker has pointed out, much of Boas' framework for anthropology at Columbia followed the existing trajectory established by amateur anthropologists earlier in the century, including the four-field system [57: III; 74].

15 An early student in the ethnography of body movement, including walking, was sociologist Marcel Mauss [76: 271-293].. 
79: 30-126]. The pendulum swing between data collection and concept synthesis lies at the heart of anthropology.

Indigenous anthropology developed alongside Western models. Translator George Hunt was a Tlingit / English metis who assisted Franz Boas and others in British Colombia and Alaska, becoming a celebrated ethnologist in his own right. Some mediated cross-cultural issues, such as Sarat Chandra Roy, who served in the colonial judicial system for Bengal. He cultivated an appreciation for tribal society, published widely and, in 1921, established Man in India, the country's first journal of anthropology. These resident anthropologists had the benefit of already being in the field and knowing the local languages and local societies. What they usually lacked were connections to bases of power, a common problem of centre / periphery scholarship [80; 81: 132-171; 82: 146-150; 83: 98-105].

Culture came to be understood as a facilitator of natural selection, illustrating links between social and biological adaptation ${ }^{16}$. Anthropology also developed an awareness of society's potential for intentional transformation. This understanding resulted in contrary efforts, from the negative eugenics movement and the Holocaust to the positive accomplishments of tribal empowerment and post-conflict capacitybuilding ${ }^{17}$.

Anthropologists tend to adopt two general strategies, which can be identified as materialist and mentalist approaches. The materialist approach leans towards tangible, evolutionary models, like cultural ecology, as seen in the work of Lucy Mair, while the mentalist approach engages psychological and symbolic analysis, like structuralism, as employed by Claude Lévi-Strauss ${ }^{18}$. Ironically, anthropologists themselves mirrored the social structures studied. The materialist and mentalist approaches can be thought of as anthropology's two moieties, while their thematic studies can be thought of as clans, and, as in tribal structures, these groups interacted in complex ways. Anthropology thus became a society in its own right.

As a result of such professional tribalism, many scholars had been professionally limited in the anthropological discourse. The depreciation of women, people of colour and those from non-elite social orders delayed the study of topics that anthropology would later come to address. This is seen in Zora Neale Hurston's work on internal colonialism, Irawati Karve's emic study of caste and kinship, and Arnold Van Gennep's reassessment of the individual in society [94: 49-67; 95:360-416; 96; 97 : 276-292; 98].

16 In 1896, psychologist James Mark Baldwin postulated connections between biological and cultural evolution. Others continued in this investigation [84: 441-451; 85; 86: 141-174].

17 A side effect of anthropology's participation in projects of social engineering has been a temporary decline of the field in some areas, as in post-Nazi Germany and post-British India. In other locales, partisan visions of the field have struggled, as in the United States and Russia during and after the Cold War [87: 14-20; 88: 255-264; 89: 326-330; 90: 399-408].

18 William Haviland and his colleagues elegantly defined this dichotomy in anthropology as materialist and mentalist approaches [91: 67-68; 92; 93]. 


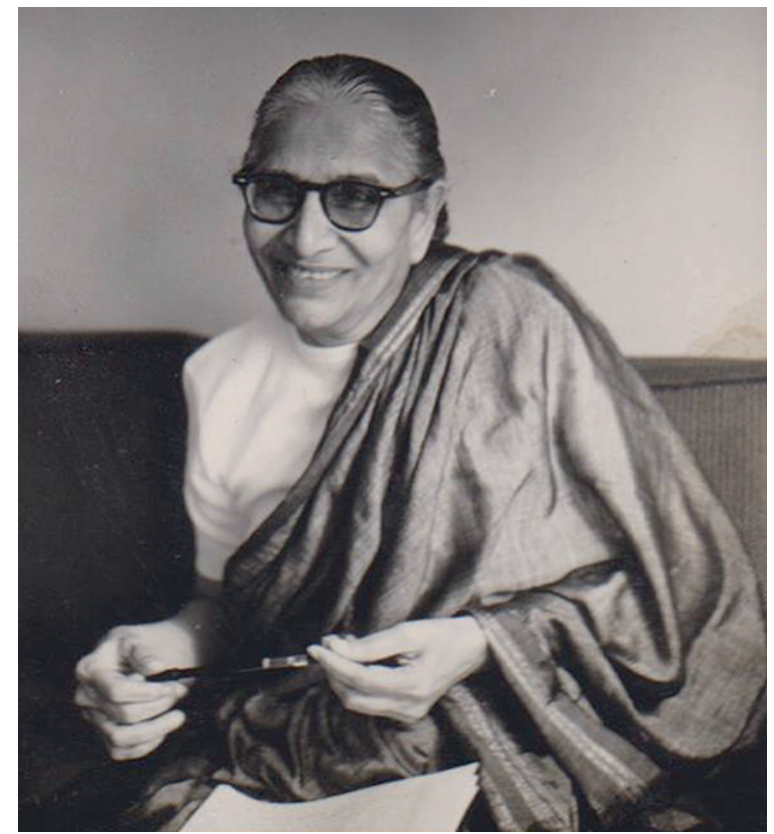

Image 8. Anthropologist Irawati Karve conducting a field interview, Maharashtra, India c1960. Photograph courtesy of the Karve Family, Pune, Maharashtra, India

Рис. 8. Антрополог Иравати Карве проводит полевой опрос, Махараштра, Индия, ок. 1960 г. Фотография предоставлена семьей Карве, Пуна, Махараштра, Индия

The flowering of diversity, technology and global contacts by the mid-twentieth century allowed anthropology to expand its repertoire. As Sally Slocum observed: 'It is our task, as anthropologists, to create a "study of the human species" in spite of, or perhaps because of, or maybe even by means of, our individual biases and unique perspectives' [99: 50] ${ }^{19}$.

The expansion of field research and translation of existing materials into more world languages led to discussion of previously inaccessiblematerials and better understanding of the history of humanity. This, in turn, led to an expansion of knowledge and theory in anthropology ... but not without challenges. It was, and is, a process.

For example, investigation of hominid arrival in the Americas took a contentious trajectory. In the 1930s, discovery of large projectile points in eastern New Mexico led to identification of Clovis culture, a hunting and foraging society centred in North America about 15,000 years ago. It was diagnosed as being carried by the first humans in the hemisphere. As other discoveries were said to pre-date Clovis traditions, mainstream scholars became sceptics, in part because of claims based on analytical techniques then being pioneered, like radiocarbon dating. The debate became rancorous. But, by the late twentieth century, new understandings developed alongside new technology, such as genomic sequencing, and more comparative samples, so a more open discussion about earlier settlement successfully began [101: 50-57; 102: 543-561; 103: 225-229].

19 Clifford Geertz noted an additional problem of anthropology in that practitioners had largely restricted their readings to those of other anthropologists up until the 1960s [100: 611]. 


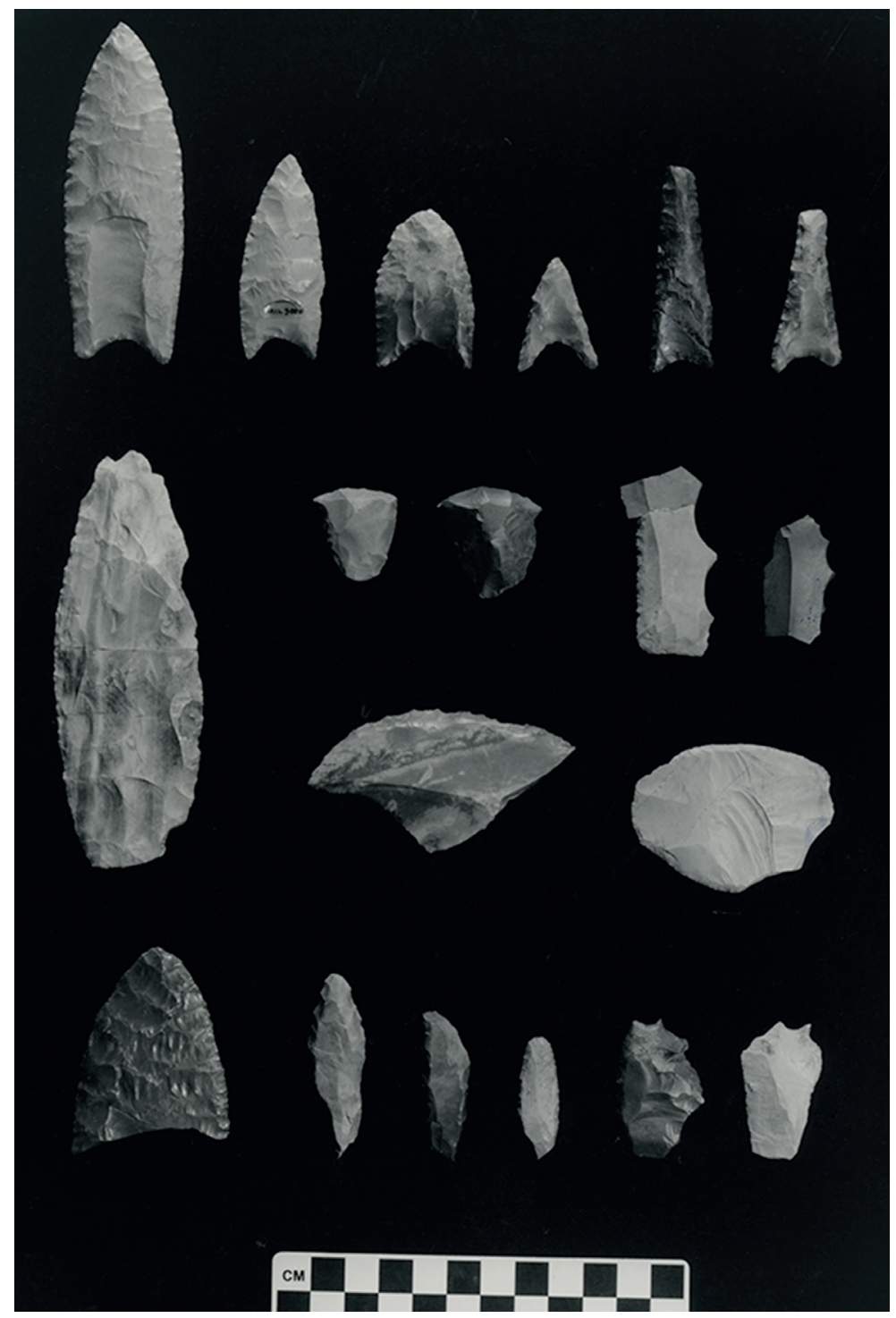

Image 9. Clovis tradition tools from the Vail Paleo-Indian encampment, Megalloway River, Maine (USA).

Image courtesy of the Maine State Museum

Рис. 9. Традиционные орудия культуры Кловис с палеоиндейской стоянки Вейл, река Магаллоуэй, Мэн, США.

Фото предоставлено с разрешения Государственного музея штата Мэн

Similarly, the role of mountain regions in human culture is acknowledged as important in human geography, but such scholarship often has been neglected [104: $60-74]$. A reason is that mountains and their watersheds frequently serve as borders, so access has been problematic. Identities and cultures solidify behind boundaries, where national rigidity of languages, publications and conferences take place. It has been easier to conduct research in more accessible and benign areas, such as of fertile plains within nations, which has revealed much information but has also reinforced nation-state visions. These boundaries, though, did not apply in past times, which has hampered mountain / border scholarship. 


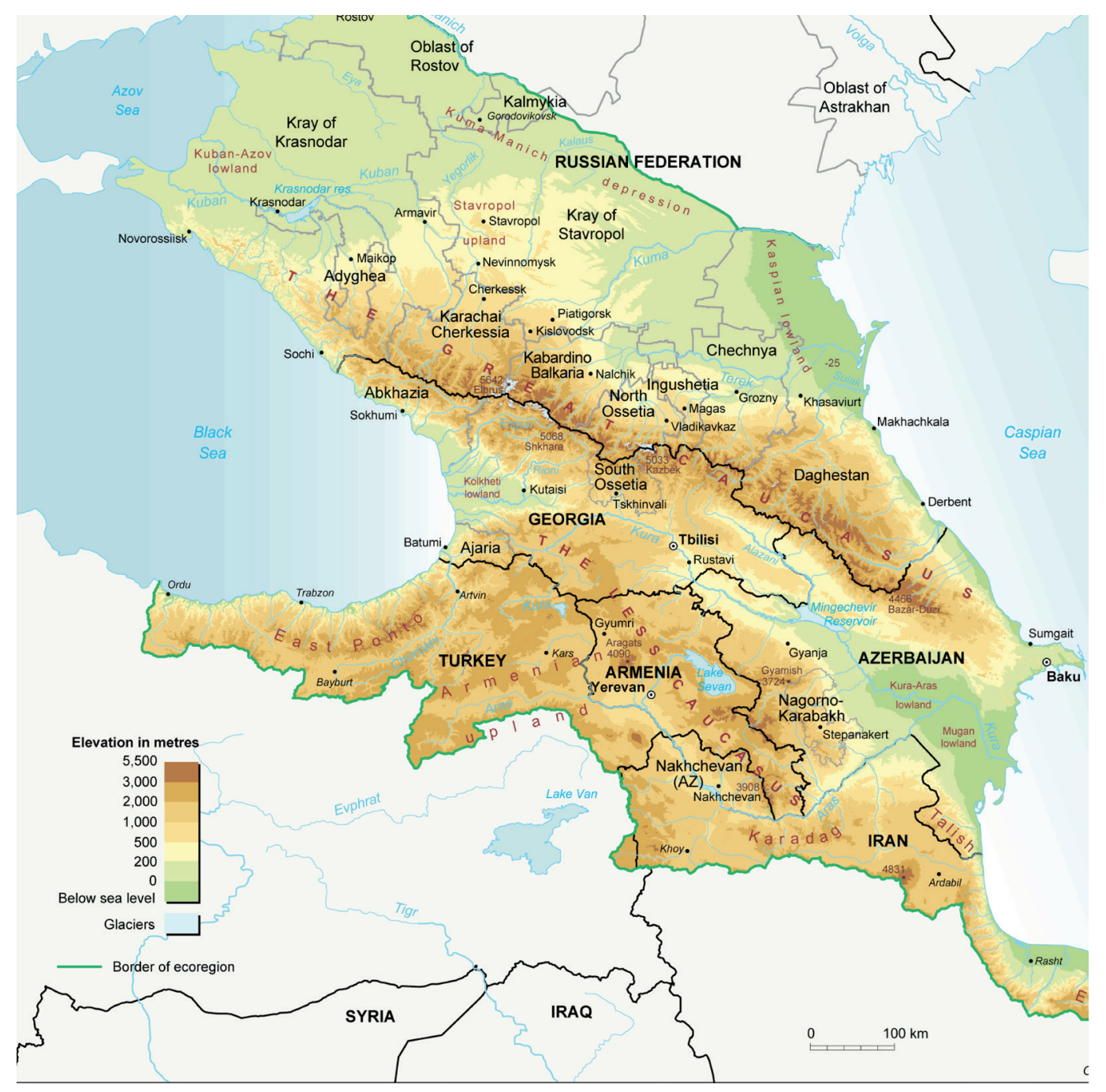

Image 10. Caucasus cartography. Wikimedia Commons

Рис. 10. Кавказская картография. Wikimedia Commons

One of these regions has been the Caucasus, a rhomboid-shaped highland of 200,000 square kilometres between the Black and Caspian seas. Presently a rich but ethnically complex and conflicted boundary zone, the Caucasus holds valuable clues for understanding hominin populating of the world. Having a generally rugged upland landscape that afforded protection and resources, its lowlands served as a gateway between regions of Eurasia. The Caucasus especially provides an important window on humanity's early history, as artefacts for the full range of the Palaeolithic lie in this compact area, one of the few such locales in the world [105: 105-116].

When the ice-age climate permitted, one of the routes for Homo erectus and its successor species in their trek out of Africa lay through the eastern Caucasus, along the Caspian Sea, a well-watered and relatively bountiful lowland that provided access to both the European plains and the Asian steppes. The earliest sites are Oldowan remains of just over two million years age, while the richest are Neanderthal and 
Early Modern Humans of the Middle Palaeolithic (300,000 to 50,000 BP). Its use as a migration corridor continued into the Upper Palaeolithic and shows diversification: A local tradition developed in the south Caucasus that was linked to western Asia, while remains in the north-west Caucasus was linked to eastern Europe [105: 105-116].

During the Neolithic, a farming tradition extended itself from Mesopotamia into Dagestan. Despite later population movements into the Caucasus, studies show an evolving linguistic and genetic homogeneity of the early resident peoples, which coexisted with newer arrivals [106: 181-191; 107: 2023-2028]. As with the debate on Clovis culture in North America, it takes special multi-tasking scholars to bridge such challenges, but such efforts have begun to proliferate.

Heritage came to be seen as a product of all humanity, as a 'commons'. In this tradition, the first edition of the United Nations' History of Humanity came out in 1966, followed by a network of World Heritage Sites a decade later [108; 109; 110: 101-133; 111]20. Curator and historian Neil MacGregor at the British Museum pioneered a new way to envision artefacts as a shared human experience, an expression of 'global civilization'21. A recent text on anthropology describes this agenda:

In our rapidly changing and increasingly interconnected world, where longstanding cultural boundaries between societies are being erased, new social networks and cultural constructs have emerged, made possible by long-distance mass transportation and communication technologies. To better describe, explain, and understand these complex but fascinating dynamics in a globalizing world, anthropologists today are adjusting their theoretical frameworks and research methods and approaches. [91: 47].

The older areas of concern to anthropology, such as kinship and tool use, expanded and came to have a continuum with other disciplines, from psychology and engineering to medicine and demographics. Advances in cognitive and neurological science led to the study of human brains and behaviour. Older dichotomies were elaborated by richer varieties, as when LGBT awareness amplified the study of sexuality and gender, which brought into question other binary categories. Applied anthropology began to resolve problems with new subfields and techniques, from cyberethnography and metagenomics to hyperspectral imaging22.

20 This diversification of anthropology was similar to the re-envisioning of Western Civilization as Global Civilization, a crediting of the reality of the field in its full context [112].

21 Neil MacGregor, presentation, and conversation with Barry Rodrigue, Symbiosis School for Liberal Arts, 31 January 2018. MacGregor's discourse was part of the exhibit, India and the World: A History in Nine Stories, mounted by the Chhatrapati Shivaji Maharaj Vastu Sangrahalaya (Mumbai), the British Museum (London), and the National Museum (New Delhi). For reference to MacGregor's theses, see [113].

22 An example of this broadening of anthropology across the boundaries of disciplines is a recent edition of Science News Magazine that featured the theme of 'protein archaeology', which presented advances in understanding protein synthesis and how it informs us about more expansive aspects of evolution. The magazine's featured article was Jennifer Michalowski, 'Proteins of the Past: Reconstructing Tiny Pieces of History Deepens Understanding of Evolution [114: 16-20]. 


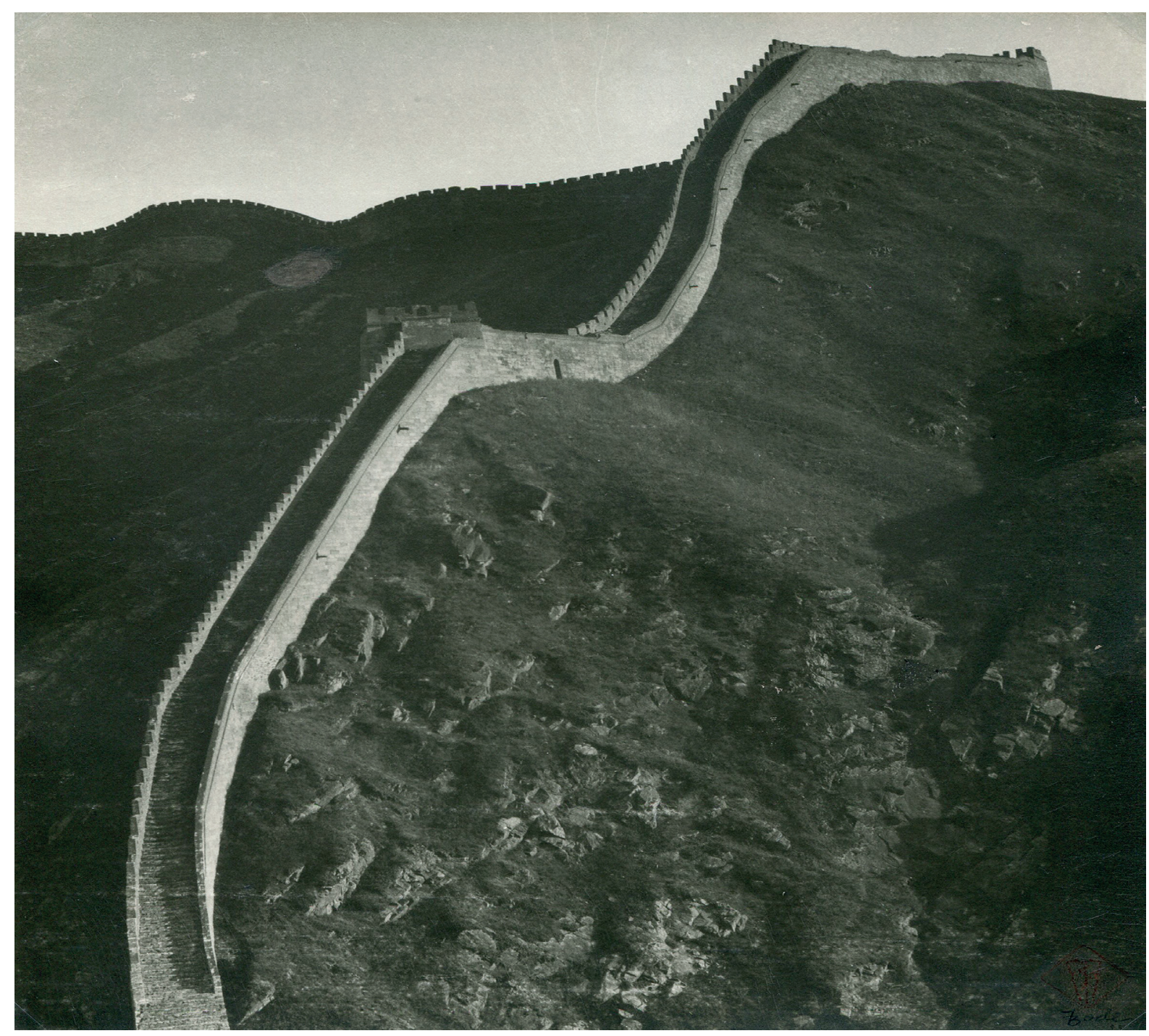

Image 11. Green Dragon Bridge, Nankau Pass,

Great Wall of China, photograph by Frances Bode, c 1929.

Bode was a pioneering woman who photographed social settings around the world for textbooks; her work is held at the Museum of Modern Art in New York City.

Courtesy of Penelope Markle

Рис. 11. Мост Зеленый Дракон,

недалеко от прохода Нанкау, Великая Китайская Стена, фотография Фрэнсис Боде, ок. 1929 г. Боде была первой женщиной, запечатлевшей социальные установки по всему миру для написания учебника, ее работа хранится в Музее Современного Искусства в Нью-Йорке. Любезно предоставлено Пенелопой Маркл

Among the important lessons to be derived from studying social systems is how many of our cultural traditions are of relatively recent origin. Only four sets of parents take us back to a century ago. By such calculations, we are but 100 generations removed from the Egyptian pyramids and the Great Wall of China, 500 from the start of agriculture, and 5000 from the human migration out of Africa. Those 10,000 people are the size of a small town's population - the May Day Stadium in Pyongyang, North Korea holds more than ten times that number! Nonetheless, in those few 
generations, humanity has developed extraordinary social abilities that far surpass other life forms on Earth and lead scholars to wonder about our potential abilities to effect larger changes in the multiverse ${ }^{23}$.

When we look at our existence through the lens of anthropology, our spotlight is by definition on ourselves, Homo sapiens. As in Paul Gauguin's painting, D'où Venons Nous / Que Sommes Nous / Où Allons Nous - we want to know where we came from, what is happening now, and where we are going. This hominid vision has been critiqued, and change is being suggested to expand anthropology to even wider realms. Just as humans grew out of a focus on their own kin and tribe to global humanity, so are we now in the process of expanding into a much more generous vision of existence. Indeed, a number of anthropologists are also big historians and have been engaged in seeking wider understanding of this more universal outlook ${ }^{24}$.

23 These calculations are, of course, rough estimates, as there were many variables, including how previous societies encouraged having children much earlier in life than does modern industrial society. Among those who contemplate humanity's potential to bring about change in the multiverse are the following [115: 317-338; 116: 370-402; 117: 403-436].

24 Professor Zhu Weibin of Sun Yat-sen University noted the connection of Gauguin's work to human studies and big history [118: 323n5]. Among the big historians who are anthropologists are Andrey Korotayev, Dmitri Bondarenko, Magomedkhan Magomedkhanov, and Nikolay Kradin. This preponderance of Russian anthropologists highlights the macro-perspective in Soviet and post-Soviet scholarship. Big historian Fred Spier has written of his development into big history by way of biochemistry, sociology and anthropology [119: 253-26o]. In addition, there are many other scholars from other disciplines who are engaged in cultural studies. 


\section{REFERENCES}

1. Tom Gehrels, 'The Chandra Multiverse', in From Big Bang to Galactic Civilizations: A Big History Anthology, Volume III, The Way that Big History Works: Cosmos, Life, Society and our Future, eds. Barry Rodrigue, Leonid Grinin and Andrey Korotayev, Delhi: Primus Books, 2017.

2. Osama Amin, 'The Newly Discovered Tablet V of the Epic of Gilgamesh', Ancient History Et Cetera, 24 September 2015, <http:// etc.ancient.eu/exhibitions/giglamesh-enkiduhumbaba-cedar-forest-newest-discoveredtablet-v-epic/>, accessed 25 November 2017.

3. Manuel Vaquero et al., 'Temporal Nature and Recycling of Upper Paleolithic Artifacts: The Burned Tools from the Molí del Salt Site (Vimbodí i Poblet, northeastern Spain)', Journal of Archaeological Science, vol. 39, no. 8, August 2012: 2785-2796.

4. Quaternary International, vol. 361, The Origins of Recycling: A Paleolithic Perspective, March 2015.

5. Barbara Gilli, 'The Past in the Present: The Reuse of Ancient Material in the 12th Dynasty', Aegyptus, vol. 89, nos. 1-2, 2009: 89-110.

6. Wilhelm Nicolaisen, "Distorted Function" in Material Aspects of Culture', Folklore Forum, vol. 12, nos. 2-3: 223-235.

7. Zhenoao Xu, David Pankenier and Yautias Jiang, East-Asian Archaeoastronomy: Historical Records of Astronomical Observations of China, Japan and Korea, Boca Raton: CRC Press, 2000: 13-24.

8. Tao Qi, 'Echoes of the Palaeolithic: A Research Note on the Great Floods and the Origins of Chinese Civilization', in From Big Bang to Galactic Civilizations: A Big History Anthology, Volume III, The Ways that Big History Works: Cosmos, Life, Society and Our Future, eds. Barry Rodrigue, Leonid Grinin, Andrey Korotayev, Delhi: Primus Publishing, 2017.

9. Dmitri Bondarenko and Ken Baskin, 'Big History, Complexity Theory, and Life in a NonLinear World,' in From Big Bang to Galactic Civilizations: A Big History Anthology, Volume III, The Ways that Big History Works: Cosmos, Life, Society and Our Future, Barry Rodrigue, Leonid Grinin, Andrey Korotayev (editors), Delhi: Primus Publishing, 2017, pp. 183-196.

10. Lazar Puhalo, 'The Rise of Personhood:
Development of Social Justice and Natural Rights in the Axial Eras', ibid, Volume II, Education and Understanding: Big History around the World, eds. Barry Rodrigue, Leonid Grinin, Andrey Korotayev, Delhi: Primus Publishing, 2016: 118-123.

11. Giuseppe Barbone et al., 'La roccia con incisioni del Monte Cònero: relazione preliminare', Preistoria Alpina, vol. 46, no. 2, 2012: 93-98.

12. Rodolfo Coccioni et al., Carta Geologica con Itinerari Escursionistici: Firenze, Italia, Parco Regionale del Conero, (1:20,000) Florence: SELCA, 1993.

13. Gaia Pignocchi et al., I Petroglifi Preistorici del Monte Cònero: Progetto di Studio $e$ Valorizzazione, Ancona: submitted to the administration of Conero Park, 8 May 2007.

14. United Kingdom, Department for Culture, Media and Sport, Portable Antiquities Scheme, Tisbury Hoard, WILT-E8DA70, <https://finds. org.uk/database/artefacts/record/id/467433>, accessed 23 April 2017.

15. Richard Gartner, Metadata: Shaping Knowledge from Antiquity to the Semantic Web, Cham: Springer, 2016.

16. The Bisotun inscription is a UNESCO World Heritage Site. United Nations Educational, Scientific and Cultural Organization, World Heritage Centre, List: Bisotun, <http://whc. unesco.org/en/list/1222>, accessed 23 April 2017.

17. Stewart Flory, 'Who Read Herodotus' Histories?' The American Journal of Philology, vol. 101, no. 1, Spring 1980: 12-28.

18. Jacques Lezra and Liza Blake, eds., Lucretius and Modernity: Epicurean Encounters Across Time and Disciplines, New York: Palgrave Macmillan, 2016.

19. Adina Hoffman, Sacred Trash: The Lost and Found World of the Cairo Geniza, New York: Schocken, 2011.

20. Amitav Ghosh, In an Antique Land, New Delhi: Ravi Dayal Publishers, 1992.

21. Stephen Haw, Marco Polo's China: A Venetian in the Realm of Khubilai Khan, London: Routledge, 2006.

22. John Rowe, 'The Renaissance Foundations of Anthropology', American Anthropologist, vol. 67, no. 1, February 1965, pp. 1-20.

23. Tim Murray, Milestones in Archaeology: 
A Chronological Encyclopedia, Santa Barbara: ABC-Clio, 2007.

24. Caroline Roullier et al., 'Historical Collections Reveal Patterns of Diffusion of Sweet Potato in Oceania Obscured by Modern Plant Movements and Recombination', Proceedings of the National Academy of Sciences of the United States of America, vol. 110, no. 6, 5 February 2013, pp. 2205-2210.

25. Kirsten Seaver, The Frozen Echo: Greenland and the Exploration of North America, ca. A.D.1000-1500, Stanford: Stanford University Press, 1996.

26. Christopher Fee, Mythology in the Middle Ages: Heroic Tales of Monsters, Magic, and Might, Santa Barbara: Praeger, 2011.

27. Sayed Ali Nadeem Rezavi, 'Antiquarian Interests in Medieval India: The Relocation of Ashokan Pillars by Firuzshah Tughluq', in Proceedings of the Indian History Congress $70^{\text {th }}$ Session, 2010.

28. Afshan Majid, Badauni and Mughal Society and Culture as Reflected in his Works, Ph.D. Thesis, Department of History, Centre of Advanced Study, Aligarh Muslim University, 2015.

29. Johann Friedrich Blumenbach, On the Natural Variety of Humankind, Göttingen: Vandenhoek \& Ruprecht, 1781 [Latin publication].

30. Peter Miller and François Louis, Antiquarianism and Intellectual Life in Europe and China, 1500-180o: A Comparative Consideration of the Fascination with Antiquity in European and Chinese Intellectual History, Ann Arbor: University of Michigan Press, 2012.

31. James Urry, Before Social Anthropology: Essays on the History of British Anthropology, London: Routledge, 1993.

32. Christopher Shea, 'Alas, Poor William Shakespeare: Where Does His Skull Rest? New York Times, 24 March 2016.

33. Walter Scott, The Antiquary, Edinburgh: James Ballantyne \& Company, 1816.

34. Gino Piovesana, 'Miura Baien, 17231789, and His Dialectic and Political Ideas', Monumenta Nipponica, vol. 20, nos. 3-4, 1965: $389-421$.

35. Lobsang Yongdan 'Tibet Charts the World: The Btsan po No mon han's Detailed Description of the World, An Early Major Scientific Work in Tibet', Mapping the Modern in Tibet, ed. Gary Tuttle, 2011: 73-134.
36. University of Cambridge, Research, 'The Tibetan Lama who Wrote a World Geography', 14 June 2014, <http://www.cam.ac.uk/research/ features/the-tibetan-lama-who-wrote-a-worldgeography>, accessed 12 June 2018.

37. Turrell Wylie, 'Dating the Tibetan Geography "Dzam Gling Rgyas Bshad" through its Description of the Western Hemisphere, Central Asiatic Journal, vol. 4, no. 4, 1959: 300311.

38. Sarat Chandra Das, A Journey to Lhasa and Central Tibet, London: John Murray, 1902: 62, 68, 108-110.

39. Alex McKay, 'The Drowning of Lama Sengchen Kyabying: A Preliminary Enquiry from British Sources', Tibet, Past and Present, eds. Henk Blezer and Abel Zadoks, Leiden: Brill, 2002: 263-279.

40. Laura Hostetler, 'Qing Connections to the Early Modern World: Ethnography and Cartography in Eighteenth-Century China', Modern Asian Studies, vol. 34, no. 3, July 2000: 623662.

41. Lalita Prasad Vidyarthi, Rise of Anthropology in India: A Social Science Orientation, Volume 1, Delhi: Concept Publishing Company, 1976.

42. Shakunt Pandey, 'The Indian Museum Completes 200 Years', Science Reporter, vol. 51, no. 10, October 2014: 38-41.

43. John Merryman, 'Thinking about the Elgin Marbles', Michigan Law Review, vol. 83, no. 8, August 1985: 1880-1923.

44. Kate Fitz Gibbon, Who Owns the Past?: Cultural Policy, Cultural Property, and the Law, New Brunswick: Rutgers University Press, 2005.

45. George Stocking Jr., Victorian Anthropology, New York: The Free Press, 1987.

46. Charles Darwin, On the Origin of Species by Means of Natural Selection, or the Preservation of Favoured Races in the Struggle for Life, London: John Murray, 1859.

47. Herbert Spencer, First Principles of a New System of Philosophy, London: Williams and Norgate, 1862.

48. Karl Marx, Capital: Critique of Political Economy, vol. 1, Hamburg: Otto Meissner, 1867 [German publication].

49. Edward Tylor, Primitive Culture: Research into the Development of Mythology, Philosophy, Religion, Art, and Custom, vols. 1-2, London: John Murray, 1871. 
50. Lewis Morgan, Ancient Society; Or, Researches in the Lines of Human Progress from Savagery, Through Barbarism to Civilization, New York: Henry Holt and Company, 1877.

51. Daniel Smail, On Deep History and the Brain, Berkeley: University of California Press, 2008.

52. Alexander von Humboldt, Kosmos, vols. 1-5, Stuttgart: J.G. Cotta Publishing, 1845-1862.

53. R. Jon McGee and Richard Warms, Anthropology Theory: An Introductory History, Lanham: Rowman \& Littlefield, 2017.

54. Robert Knox, The Races of Men: $A$ Philosophical Enquiry into the Influence of Race over the Destinies of Nations, London: Henry Renshaw, 1850, 1862.

55. Efram Sera-Shriar, The Making of British Anthropology, 1813-1871, London: Routledge, 2013, 2015.

56. Stephen Jay Gould, The Mismeasure of Man, New York: W.W. Norton, 1981, 1996.

57. Elisabeth Tooker, 'A Note on Undergraduate Courses in the Latter Part of the Nineteenth Century', Man in the Northeast, vol. 39, Spring 1990: 45-51.

58. Arthur Spiess, 'Wild Maine and the Rusticating Scientist: A History of Anthropological Archaeology in Maine':101-129, Man in the Northeast, vol. 30, Fall 1985: 104-106.

59. Christopher Benfey, The Great Wave: Gilded Age Misfits, Japanese Eccentrics, and the Opening of Old Japan, New York: Random House, 2004.

6o. Edward Morse, 'Shell Mounds of Omori', Memoirs of the Science Department, University of Tokio, Japan, Volume I, Part I, Tokyo: University of Tokyo, 1879 .

61. Shinji Yamashita, Joseph Bosco and Jeremy Eades, The Making of Anthropology in East and Southeast Asia, New York: Berghahn Books, 2004.

62. British Association for the Advancement of Science, Notes and Queries on Anthropology: For the Use of Travellers and Residents in Uncivilized Lands, London: Edward Stanford, 1874: IV.

63. Susan Brownell, The 1904 Anthropology Days and Olympic Games: Sport, Race, and American Imperialism, Lincoln: University of Nebraska Press, 2008.

64. Rosemarie Bank, "Show Indians"/Showing Indians: Buffalo Bill's Wild West, the Bureau of Indi- an Affairs, and American Anthropology', Journal of Dramatic Theory and Criticism, vol. 26, no. 1, Fall 2011: 149-158.

65. Bruce Trigger, A History of Archaeological Thought, Cambridge: Cambridge University Press, 1990, viz. 'Archaeology and its Social Context'.

66. Mingxin Liu, 'A Historical Overview on Anthropology in China', Anthropologist, vol. 5, no. 4, 2003: 217-223. Available from: <http:// krepublishers.com/o2-Journals/T-Anth/ Anth-05-0-000-000-2003-Web/Anth-05-4217-303-2003-Abst-PDF/Anth-05-4-217-2232003-143-Liu-M/Anth-05-4-217-223-2003143-Liu-M-Text.pdf>, accessed 13 April 2017.

67. Andrew Christenson, 'Who were the Professional North American Archaeologists of 1900? Clues from the Work of Warren K. Moorehead,' Bulletin of the History of Archaeology, vol. 21, no. 1, May 2011: 6, 13, 17.

68. Jay Bernstein, 'First Recipients of Anthropological Doctorates in the United States, 1891-1930, American Anthropologist, vol. 104, no. 2, 2002: $551-564$.

69. Reba Soffer, 'The Development of Disciplines in the Modern English University', The Historical Journal, vol. 31, no. 4, December 1988: 933-946.

70. Alfred Russel Wallace, 'Peschel's "Races of Man", Nature, vol. 15, 28 December 1876: 174 .

71. Curtis Hinsley, The Smithsonian and the American Indian: Making a Moral Anthropology in Victorian America, Washington DC: Smithsonian Institution Press, 1981, 1994.

72. Stiofán Ó Cadhla, Civilizing Ireland: Ordnance Survey 1824-1842: Ethnography, Cartography, Translation, Dublin: Irish Academic Press, 2007.

73. Indra Sengupta, 'A Conservation Code for the Colony: John Marshall's Conservation Manual and Monument Preservation Between India and Europe', in 'Archaeologizing' Heritage?: Transcultural Entanglements between Local Social Practices and Global Virtual Realities, eds. Michael Falser and Monica Juneja, Berlin: Springer-Verlag: 21-37.

74. Wilhelm Wundt, Völkerpsychologie: Eine Untersuchung der Entwicklungsgesetze von Sprache, Mythus und Sitte; Mythus und Religion, vol. 2, part 1, Leipzig: Wilhelm Engelmann, 1905:, III [German publication]. 
75. Ruth Benedict, Patterns of Culture, Boston: Houghton Mifflin Company, 1934.

76. Marcel Mauss, 'Les techniques du corps', Journal de Psychologie, vol. 32, nos. 3-4, 15 March 1936: 271-293.

77. Franz Boas, 'Ethnology of the Kwakiutl: Based on Data Collected by George Hunt', 35th Annual Report of the Bureau of American Ethnology, Parts 1 and 2, Washington DC: Bureau of American Ethnology, 1921.

78. Bronislaw Malinowski, Argonauts of the Western Pacific: An Account of Native Enterprise and Adventure in the Archipelagoes of Melanesian New Guinea, London: G. Routledge \& Sons, 1922.

79. Marcel Mauss, 'Essai sur le don: Forme et raison de l'échange dans les sociétés archaïques', L’Année Sociologique, vol. 2, no. 1, 1925: 30-126.

80. Theodore Timreck, dir., Franz Boas, 1858-1942, Public Broadcasting Associates, 1980.

81. Sangeeta Dasgupta, 'Recasting the Oraons and the "Tribe", in Anthropology in the East: Founders of Indian Sociology and Anthropology, eds. Patricia Uberoi, Nadini Sundar and Satish Deshpande, Ranikhet: Permanent Black, 2007: 132-171.

82. Sarat Chandra Roy, 'An Indian Outlook on Anthropology', Man (Journal of the Royal Anthropological Institute), vol. 38, no. 9, September 1938: 146-150.

83. Mondher Kilani, 'Is a Peripheral Anthropology Possible? The Issue of Universalism', Kroeber Anthropological Society Papers, vol. 101, no. 1, 2012: 98-105.

84. James Mark Baldwin, 'A New Factor in Evolution', The American Naturalist, vol. 30, no. 354, June 1896: 441-451.

85. Bruce Weber and David Depew, Evolution and Learning: The Baldwin Effect Reconsidered, Cambridge: MIT Press, 2003.

86. Leonid Grinin, Andrey Korotayev and Alexander Markov, 'Biological and Social Phases of Big History: Evolutionary Principals and Mechanisms', in From Big Bang to Galactic Civilizations: A Big History Anthology, Volume III, The Way that Big History Works: Cosmos, Life, Society and our Future, eds. Barry Rodrigue, Leonid Grinin and Andrey Korotayev, Delhi: Primus Books, 2017: 141-174.

87. David Price, 'Lessons from Second World War Anthropology: Peripheral, Persuasive and
Ignored Contributions', Anthropology Today, vol. 18, no. 3, June 2002: 14-20.

88. Shweta Sinha Deshpande, 'India: Evolving a Big History', in From Big Bang to Galactic Civilizations: A Big History Anthology, Volume II, Education and Understanding: Big History around the World, Barry Rodrigue, Leonid Grinin, Andrey Korotayev (editors), Delhi: Primus Publishing, 2016: 255-264.

89. Jean-Yves Durand, "Traditional Culture" and "Folk Knowledge": Wither the Dialogue between Western and Post-Soviet Anthropology?', Current Anthropology, vol. 16, no. 2, April 1995: 326-330.

90. Roy D'Andrade, 'Moral Models in Anthropology', Current Anthropology, vol. 16, no. 3, June 1995: 399-408.

91. William Haviland et al., Cultural Anthropology: The Human Challenge, Boston: Cengage Learning, 2017.

92. Lucy Mair, Primitive Government, Harmondsworth: Penguin Books, 1962.

93. Claude Lévi-Strauss, The Savage Mind, Paris: Librairie Plon, 1962 [French publication].

94. Irma McClaurin, 'Zora Neale Hurston: Enigma, Heterodox, and Progenitor of Black Studies', Fire!!!: The Multimedia Journal of Black Studies, vol. 1, no. 1, March 2012: 49-67.

95. Nandini Sundar, 'In the Cause of Anthropology: The Life and Work of Irawati Karve', in Anthropology in the East: Founders of Indian Sociology and Anthropology, eds. Patricia Uberoi, Nadini Sundar and Satish Deshpande, Ranikhet: Permanent Black, 2007: $360-416$.

96. Nicole Belmont, Arnold Van Gennep: Le Créateur de l'ethnographie française, Paris: Payot, 1974.

97. Marilyn Strathern, 'An Awkward Relationship: The Case of Feminism and Anthropology', Signs: Journal of Women in Culture and Society, vol. 12, no. 2, Winter 1987: 276-292.

98. Susan Seymour, Cora DuBois: Anthropologist, Diplomat, Agent, Lincoln: University of Nebraska Press: 2015.

99. Sally Slocum, 'Woman the Gatherer: Male Bias in Anthropology', in Toward an Anthropology of Women, ed. Rayna Reiter: New York: Monthly Review, 1975: 50.

100. Clifford Geertz, 'An Interview with 
Clifford Geertz', by Richard Handler, Current Anthropology, vol. 32, no. 5, December 1991: 611.

101. George Agogino, 'Man's Antiquity in the Western Hemisphere', in The American Indian Reader: Anthropology, San Francisco: American Indian Educational Publishers, 1972: 50-57.

102 Herbert Klein, 'The First Americans: The Current Debate', Journal of Interdisciplinary History, vol. 46, no. 4, Spring 2016: 543-561.

103. Morten Rasmussen et al., 'The Genome of a Late Pleistocene Human from a Clovis Burial Site in Western Montana', Nature, vol. 506, no. 7487, 13 February 2014: 225-229.

104. Andrey Korotayev, 'Mountains and Democracy', in Alternative Pathways to the Early State, vol. 1, eds. Nikolay Kradin and Valeri Lynsha, Vladivostok: Far East Branch of the Russian Academy of Sciences / Dal'nauka, 1996: 60-74.

105. Sergey Vasilyev and Hizri Amirkhanov, 'Paleolithic Caucasus: Paleoanthropological Panorama', Quaternary International, vol. 465, part A, 20 January 2018: 105-116.

106. Tatiana Karafet et al., 'Co-Evolution of Genes and Languages and High Levels of Population Structure among the Highland Populations of Daghestan', Journal of Human Genetics, vol. 61, no. 3, March 2016: 181-191. 107. Ashot Margaryan, et al., 'Eight Millennia of Matrilineal Genetic Continuity in the South Caucasus', Current Biology, vol. 27, no. 13, 7 October 2017: 2023-2028.

108. United Nations, History of Humanity, Paris: United Nations Educational, Scientific and Cultural Organization, 1966, 2009;

109. International Commission for a History of the Scientific and Cultural Development of Mankind, <http://atom.archives.unesco. org/international-commission-for-historyof-scientific-and-cultural-development-ofmankind-2;isad>, accessed 4 December 2014.

110. Poul Duedahl, 'Selling Mankind: UNESCO and the Invention of Global History, 1945-1976', Journal of World History, vol. 22, no. 1, March 2011,: 101-133.

111. United Nations Educational, Scientific and Cultural Organization, 'World Heritage List', <https://whc.unesco.org/en/list/>, accessed 13 April 2018.

112. Enrico Bertacchini et al., eds., Cultural Commons: A New Perspective on the Production and Evolution of Cultures, Cheltenham: Edward Elgar Publishing, 2012.

113. Neil MacGregor, A History of the World in 100 Objects, London: Allen Lane, 2010.

114. Jennifer Michalowski, 'Proteins of the Past: Reconstructing Tiny Pieces of History Deepens Understanding of Evolution', Science News Magazine, vol. 189, no. 12, 11 June 2016: 16-20.

115. Akop Nazaretyan, 'Life's Meaning as a Global Problem of Modernity: A View from a Big History and Complexity-Studies Perspective', in From Big Bang to Galactic Civilizations: A Big History Anthology, Volume III, The Ways that Big History Works: Cosmos, Life, Society and Our Future, eds. Barry Rodrigue, Leonid Grinin, Andrey Korotayev, Delhi: Primus Publishing, 2017: 317-338.

116. Alexander Panov, 'Singularity of Evolution and Post-Singular Development', in From Big Bang to Galactic Civilizations: A Big History Anthology, Volume III, The Way that Big History Works: Cosmos, Life, Society and our Future, New Delhi: Primus Books, 2017: 370402.

117. Joseph Voros, 'Big Futures: MacroHistorical Perspectives on the Future of Humankind', in From Big Bang to Galactic Civilizations: A Big History Anthology, Volume III, The Way that Big History Works: Cosmos, Life, Society and our Future, New Delhi: Primus Books, 2017: 403-436.

118. Weibin Zhu, 'Big History and World History in China's Colleges and Universities', in From the Big Bang to Galactic Civilizations: A Big History Anthology, Volume II, Education and Understanding: Big History around the World, eds. Barry Rodrigue, Leonid Grinin, Andrey Korotayev, Delhi: Primus Books, 2016: $323 n 5$.

119. Fred Spier, 'Roads towards Big History', in From Big Bang to Galactic Civilizations: A Big History Anthology, Volume III, The Ways that Big History Works: Cosmos, Life, Society and Our Future, Barry Rodrigue, Leonid Grinin, Andrey Korotayev (editors), Delhi: Primus Publishing, 2017: 253-260. 